\title{
Pengaruh Pemberian Zat Pengatur Tumbuh Atonik Dan Media Tanam Terhadap Pembibitan Tanaman Aren Genjah (Arenga pinnata, Merr)
}

\section{The Influence of Substance Growth Regulator Atonik And Media Planting Against Aren Genjah Plant Seedlings (Arenga pinnata, Merr)}

\author{
Yanti Ratna Sari ${ }^{1}$, Tutik Nugrahini ${ }^{2}$, Mahdalena ${ }^{2}$ \\ ${ }^{1}$ Alumni Program Studi Agroteknologi, Fakultas Pertanian, Universitas Widya Gama Mahakam \\ ${ }^{2}$ Tenaga Pendidik Program Studi Agroteknologi, Fakultas Pertanian, Universitas Widya Gama Mahakam \\ Jl. KH. Wahid Hasyim, Sempaja, Samarinda, Kalimantan Timur, Indonesia \\ email : yantirsari@gmail.com, tutiknugrahini@uwgm.ac.id, mahdalena@uwgm.ac.id
}

Diterima : 17 Mei 2017 Disetujui : 2 Juni 2017

\begin{abstract}
The Influence of Atonic Growth Substance and Planting Media Against Aruh Genjah Plant Breeding (Arenga pinnata, Merr). This study aims to determine the effect of proper growth regulator concentration and the best planting medium for the growth of palm seedlings, as well as the effect of interaction between ZPT Atonik and planting media. This research was conducted in Sangatta Lama area of Sangatta Utara Sub-district, East Kutai Regency, with time for 5 (five) months from February to June 2016. The research design used Factorial Randomized Block Design (RAK) $4 \times 4$ with 3 repetition. The first factor was the administration of Atonic ZPT consisting of 4 levels: z0: without treatment, z1: Atonic ZPT $0.5 \mathrm{ml} / 1$ liter water, z2: ZPT Atonik $1 \mathrm{ml} / 1$ liter water, z3: ZPT Atonic $1.5 \mathrm{ml} / 1$ liter of water. The second factor is the comparison of planting medium consisting of 4 levels: m0: top soil, m1: top soil + sand + manure (1:1:1), m2: top soil + husk husk + manure (1: 1: 1 ), m3: top soil + charcoal husk + sand + manure (1: 1: 1:1). Fingerprint analysis showed that the best effect of ZPT Atonik (Z) on the parameters of plant height was on the first month that is in the treatment of z2 (Atonic ZPT $1 \mathrm{ml} / 1$ liter water). The best comparison of planting medium $(M)$ to plant height parameters was at month 2 and month 3 was achieved by treatment of $m 2$ (top soil + husk husk + manure $=1: 1: 1)$ and $m 3$ treatment $($ Top soil ++ Sand + manure $=1$ : 1: 1: 1). Furthermore, the best treatment of leaflet parameter of month 1 was achieved by treatment of $m 1$ (top soil + sand + manure = 1: 1: 1). The interaction of ZPT Atonik (zxm) comparison and the best planting medium to the leaf number parameter is the 1st month achieved by the z3pl treatment (Atonic ZPT $1.5 \mathrm{ml} / 1$ liter water and top soil + sand + manure $=1: 1: 1)$.
\end{abstract}

Keywords: Growing Regulators, Planting Media and Aren Genjah

\section{PENDAHULUAN}

Aren (Arenga pinnata, Merr) termasuk jenis tanaman palma yang serbaguna dan tersebar pada hampir seluruh wilayah Indonesia. Tumbuh pada ketinggian 0-1500 meter di atas permukaan laut. Aren juga dapat dibudidayakan sebagai tanaman sela dan reboisasi untuk konservasi lahan, tanpa menimbulkan persaingan dengan tanaman pangan lainnya (Lempang, 2000).

Secara alami pertumbuhan tanaman aren berkelompok sehingga ada anggapan bahwa tanaman aren (Arenga pinnata, Merr) membentuk anakan/bertunas. Hal ini disebabkan buah matang yang jatuh di bawah pohon tumbuh menjadi tanaman dan oleh petani pemilik dibiarkan tumbuh bersama induknya. Tanaman aren akan mati setelah \pm 5 tahun berbunga. Mayang bunga yang disadap niranya adalah mayang bunga jantan, sedangkan mayang bunga betina hanya menghasilkan sedikit nira. Oleh sebab itu, mayang bunga betina tidak disadap dan dibiarkan tumbuh dan membentuk buah lainnya (Lempang, 2000).

Tanaman aren diperbanyak secara generatif, yaitu melalui biji yang berasal dari pohon induk terpilih. Di alam terdapat dua tipe aren, yaitu aren Dalam dan aren Genjah. Pada tahun 2012 Menteri Pertanian telah melepas satu varietas Aren Genjah Kutim sebagai varietas unggul yang berasal dari Kutai Timur Provinsi Kalimantan Timur.

Pengetahuan dan informasi teknologi budidaya tanaman aren masih perlu ditingkatkan, mengingat kegiatan penelitian dan pengembangan pada tanaman tersebut masih relatif terbatas. Oleh sebab itu, diseminasi inovasi teknologi dan pengembangan penelitian aren di Indonesia masih perlu ditingkatkan (Lempang, 2000).

Pemanfaatan tanaman aren di Indonesia telah berlangsung lama, namun perkembangannya menjadi komoditi agribisnis relatif lambat, karena sebagian tanaman aren yang ada tumbuh secara alamiah atau belum dibudidayakan. Budidaya tanaman aren belum banyak dilaksanakan, karena selama ini yang dilaksanakan masih terbatas pada penanganan panen, pasca panen dan aspek pemasarannya. Di beberapa daerah, tanaman aren tumbuh secara alami dengan jarak tanam yang tidak teratur. Pada umumnya tanaman aren yang dieksploitasi atau diusahakan petani tumbuh secara alami bersama dengan tanaman lain. Setelah tanaman 
aren mati, pemulihan populasi terjadi secara alami dengan sedikit campur tangan manusia, antara lain penjarangan apabila tanaman tumbuh berdekatan (Lempang, 2000).

Aren memiliki fungsi produksi menghasilkan berbagai komoditi yang mempunyai nilai ekonomi tinggi dan berpotensi ekspor jika diusahakan secara serius, karena seluruh bagian tanaman dapat diolah menjadi berbagai produk pangan dan non pangan. Nira diolah menjadi gula, minuman palm wine, nata de pinna, dan bioetanol, buah yang belum matang untuk kolang-kaling, batang menghasilkan tepung apabila niranya tidak disadap dan tepung diolah menjadi sohun, hung kwe, aren mutiara dan sebagai bahan baku pembuatan edible film.

Kayu aren digunakan sebagai bahan baku pembuatan meubel, daun untuk pembuatan atap dan lidinya untuk dibuat sapu. Ijuk dapat diolah menjadi produk kerajinan, serta akar dapat digunakan sebagai obat herbal karena mengandung senyawa-senyawa sekunder seperti saponin, flavonoid, dan polifenol. Selain itu, aren memiliki fungsi konservasi, karena tanaman ini dapat digunakan untuk pengendalian tata air tanah lainnya (Lempang, 2000).

Aren dengan perakaran yang dangkal dan melebar sangat bermanfaat untuk mencegah terjadinya erosi tanah. Demikian pula dengan daun yang cukup lebat dan batang yang tertutup dengan lapisan ijuk, sangat efektif untuk mengurangi air hujan yang langsung kepermukaan tanah. Oleh karena itu, aren dapat mencegah terjadinya erosi (Lempang, 2000).

Produk tanaman aren memiliki nilai ekonomi tinggi dan berpotensi ekspor jika diusahakan secara serius. Semua bagian tanaman dapat diolah menjadi berbagai produk pangan dan nonpangan. Salah satu produk nonpangan dari aren adalah bioetanol yang diolah dari nira. Terkait dengan isu lingkungan dan kesehatan, upaya pemenuhan kekurangan energi di masa mendatang akan diarahkan ke sumber terbarukan dan ramah lingkungan, yaitu biofuel/bioenergi salah satu diantaranya adalah bioetanol. Namun, hampir seluruh sumber bahan baku biofuel sering bersaing dengan kebutuhan pangan. Dalam konteks inilah tanaman aren dapat mengambil peran sebagai salah satu sumber biofuel yang penting karena memiliki produktivitas nira yang tinggi (Lempang, 2000).

Tahun 2011 Balai Penelitian Tanaman Palma (Balit Palma) bekerjasama dengan Dinas Perkebunan Kab. Kutai Timur telah melepas tanaman aren genjah dengan keunggulan produktivitas nira tinggi dan berproduksi pada umur 6 tahun. Oleh karena potensi produksi tanaman aren yang tinggi untuk pemanfaatan aren sebagai salah satu komoditi agribisnis, diperlukan strategi pengembangan yang tepat terutama di lahan-lahan sub optimal yang kurang produktif. Diharapkan melalui usaha pengembangan aren ini dapat meningkatkan pendapatan petani serta melestarikan sumber daya alam dan lingkungan hidup (Lempang, 2000).

Zat pengatur tumbuh atau biasa dikenal dengan hormon pertumbuhan jumlahnya sangat banyak terdapat ratusan hormon, baik yang eksogen maupun yang endogen. Pengelompokan ini untuk memudahkan identifikasi dan didasarkan terutama pada efek fisiologi yang sama, bukan semata kemiripan struktur kimia. Pada saat ini dikenal lima kelompok hormon pertumbuhan yaitu auksin, sitokinin, giberelin, etilena dan asam absitat. Tiga kelompok pertama bersifat positif bagi pertumbuhan pada konsentrasi fisiologis, etilena dapat mendukung maupun menghambat, dan asam absitat merupakan penghambat (inhibitor) pertumbuhan (Harjadi, 2009).

Media tanam merupakan salah satu komponen penting dalam bercocok tanam. Media tanam yang dipakai untuk menanam tanaman harus sesuai sehingga tanaman bisa tumbuh dengan baik. Tapi terkadang menentukan media tanam yang tepat untuk jenis tanaman agar sesuai dengan habitat asalnya cukup sulit, hal ini dikarenakan setiap daerah tempat tanaman tersebut berkembang berbedabeda. Secara umum media tanam harus bisa menjaga kelembaban daerah sekitar akar tanaman dan menyediakan cukup udara dan unsur hara. Oleh karena itu jenis media tanam yang digunakan masing-masing daerah selalu berbeda-beda. Di asia tenggara misalnya sejak tahun 1940 menggunakan media tanam dari pecahan batu bata, sabut kelapa, arang dan batang pakis. Media tanam tersebut bisa digunakan secara tunggal ataupun dikombinasikan antara bahan satu dengan bahan yang lainnya (Hanafiah, 2005).

Berdasarkan hal diatas maka perlu adanya pengetahuan budidaya yang baik serta usaha yang sungguh-sungguh memberikan kontribusi kepada para petani jika ingin mengusahakan tanaman aren genjah dimana penghasilan tambahan akan diperoleh, sebagai salah satunya adalah melakukan penelitian yang berhubungan dengan budidaya aren genjah. 


\section{BAHAN DAN METODE}

Penelitian dilaksanakan dari Februari 2016 sampai dengan Juni 2016, terhitung dari sejak persiapan media tanam sampai pengambilan data. Bibit Aren Genjah umur 1 bulan, Polybag $30 \times 20 \mathrm{~cm}$, media tanam (Top Soil, Pupuk Kandang, Arang Sekam, dan Pasir), Zat Pengatur Tumbuh (ZPT) Atonik. Tempat penelitian dilaksanakan di daerah Sangatta Lama, Kecamatan Sangatta Utara, Kabupaten Kutai Timur. Bahan yang digunakan yaitu : Bibit Aren Genjah umur 1 bulan, Polybag $30 \times$ $20 \mathrm{~cm}$, media tanam (Top Soil, Pupuk Kandang, Arang Sekam, dan Pasir), Zat Pengatur Tumbuh (ZPT) Atonik. Alat yang digunakan yaitu : hand sprayer, gembor, kamera, mikro kaliper, alat tulis, gelas ukur, dan meteran. Penelitian ini menggunakan Rancangan Acak Kelompok (RAK), dengan perlakuan faktorial $4 \times 4$ dengan jumlah ulangan 3 kali, Terdiri dari 2 faktor yaitu : Faktor pertama adalah penyiraman Zat Pengatur Tumbuh (ZPT) Atonik (Z) terdiri dari 4 taraf yaitu : $\mathrm{z}_{0}$ : tanpa perlakuan, $\mathrm{z}_{1}: \mathrm{ZPT}$
Atonik 0,5 ml/ 1 liter air, $\mathrm{z}_{2}$ : ZPT Atonik $1 \mathrm{ml} / 1$ liter air dan $\mathrm{z}_{3}$ : ZPT Atonik 1,5 ml/ 1 liter air dan faktor kedua adalah perbandingan media tanam (M) terdiri dari 4 taraf yaitu : $\mathrm{m}_{0}$ : Top soil, $\mathrm{m}_{1}$ : Top soil + pasir + pupuk kandang $(1: 1: 1), \mathrm{m}_{2} \quad$ : Top soil + arang sekam + pupuk kandang (1:1:1), $\mathrm{m}_{3}$ : Top soil + arang sekam + pasir + pupuk kandang (1:1:1:1) Jumlah kombinasi perlakuan 4 x $4=16$ kombinasi, dengan perlakuan yang di ulang sebanyak 3 kali sehingga jumlah petak penelitian sebanyak 48 polybag. Pelaksanaan penelitian meliputi ; penyediaan media tanam, penanaman bibit ke media tanam, pemberian perlakuan ZPT Atonik, pemeliharaan (penyiraman dan penyiangan). Pengambilan data meliputi ; tinggi tanaman $(\mathrm{cm})$, diameter Batang $(\mathrm{mm})$, jumlah daun (helai). Data di analisis dengan menggunakan sidik ragam, apabila ada pengaruh maka dilakukan Uji lanjutan dengan menggunakan Uji Beda Nyata Terkecil ( BNT ) pada taraf $5 \%$ untuk membandingkan dua ratarata perlakuan.

\section{HASIL DAN PEMBAHASAN}

\section{Pengaruh Zat Pengatur Tumbuh Atonik}

Tabel 1. Pengaruh Zat Pengatur Tumbuh Atonik (Z) terhadap rata-rata tinggi tanaman $(\mathrm{cm})$

\begin{tabular}{cccc}
\hline \multirow{2}{*}{ Perlakuan ZPT Atonik } & \multicolumn{3}{c}{ Tinggi tanaman } \\
\cline { 2 - 4 } & Bulan ke 1 & Bulan ke 2 & Bulan ke 3 \\
\hline $\mathrm{Z}_{0}$ & $4,92 \mathrm{~b}$ & 16,25 & 20,83 \\
$\mathrm{Z}_{1}$ & $6,54 \mathrm{a}$ & 15,67 & 19,25 \\
$\mathrm{Z}_{2}$ & $7,46 \mathrm{a}$ & 18,08 & 20,84 \\
$\mathrm{Z}_{3}$ & $6,63 \mathrm{a}$ & 14,42 & 19,34 \\
\hline
\end{tabular}

Keterangan : Angka yang diikuti huruf yang sama menyatakan tidak berbeda nyata pada BNT 5\% (BNT z = 1,41)

Hasil analisis sidik ragam menunjukkan bahwa pengaruh pemberian ZPT Atonik dengan konsentrasi $1 \mathrm{ml} / 1$ liter air (perlakuan $\mathrm{z}_{2}$ ) berpengaruh nyata pada tinggi tanaman bulan ke 1 yaitu $7,46 \mathrm{~cm}$. Berpengaruhnya pemberian ZPT Atonik dengan konsentrasi $1 \mathrm{ml} / 1$ liter air pada jumlah daun bulan ke 1, menurut Harjadi (2009), bahwa hubungan dari pertumbuhan dan kadar auksin adalah sama pada akar, daun dan tunas yaitu auksin merangsang pada kadar rendah sebaliknya menghambat pada kadar tinggi, sehingga dengan pemberian konsentrasi Atonik yang tepat akan meningkatkan pertumbuhan tinggi tanaman. Selain itu ZPT Atonik yang diberi sesuai kosentrasi yang dibutuhkan tanaman, sehingga dalam keseimbangan dengan auksin di dalam tubuh tanaman yang mempunyai peranan penting dalam meningkatkan protein, maka akan mempengaruhi proses pertumbuhan.
Hasil analisis sidik ragam menunjukkan pemberian ZPT Atonik sebesar $1 \mathrm{ml} / 1$ liter air $\left(\mathrm{z}_{2}\right)$ tidak berbeda nyata dengan pemebrian ZPT Atonik 1,5 ml/1 liter air (perlakuan $\mathrm{z}_{3}$ ) dan pembrian ZPT Atonik 0,5 ml/1liter air (perlakuan $\mathrm{z}_{1}$ ). Ini diduga disebabkan kandungan zat pengatur tumbuh yang terkandung di dalam zat pengatur tumbuh sintetik dan zat pengatur tumbuh alami, kandungan zat pengatur tumbuh alami sama dengan hormon yang terkandung dalam tubuh tanaman.

Pemberian zat pengatur tumbuh bertujuan untuk mempercepat proses fisiologis pada tanaman yang memungkinkan tersedianya bahan pembentuk organ vegetatif, sehingga dapat meningkatkan zat hara yang tersedia. ZPT Atonik merupakan zat pengatur tumbuh sintesis yang berguna untuk mempercepat dan memprbanyak keluarnya akar-akar baru, karena mengandung bhan aktif dari hasil formulasi beberapa hormon tumbuh akar yaitu 
naftalenasetamida $0,067 \%, 2$ metil 1 naftalenasetamida $0,013 \%, 2$ metil 1 naftalen asetat $0,033 \%$ indole 3 butirat (IBA) $0,057 \%$ dan tiram 4\% (Yunita, 2011). Ditambahkan Harjadi (2009), bahwa pada bagian tanam yang aktif terdapat auksin yang disintesis sehingga dapat memacu pertumbuhan sel-sel yang terdapat pada jaringan meristem, dapat dikatakan bahwa bahan aktif yang terkandung di dalam ZPT Atonik dapat bergerak dari satu bagian ke bagian lainnya sehingga mempunyai peranan dalam pembelahan sel, dan pada akhirnya akan mempengaruhi proses pertumbuhan tanaman seperti tinggi tanaman, diameter batang serta jumlah daun pada tanaman tersebut, kemudian pengaruh nyata ini diduga bahwa pemberian ZPT Atonik dapat meningkatkan sintetis protein di dalam tanah sehingga akan menjamin sel-sel baru yang memerlukan protein, dinyatakan Harjadi (2009), bahwa auksin berpengaruh terhadap perkembangan sel dengan meningkatkan tekanan osmotik sel terhadap air yang menyebabkan berkurangnya dinding sel, meningkatkan sintetis protein, meningkatkan plastisitas dan perkembangan sel, sebagai akibat pengaruh auksin ini sel-sel tersebut mengembang dan memanjang serta menyerap air, dengan demikian dihasilkan sel-sel yang besar dengan vakuola yang besar pula.

Hasil analisis sidik ragam menunjukkan bahwa pengaruh ZPT Atonik tidak berpengaruh nyata pada parameter tinggi tanaman bulan ke 2 dan ke 3 , selanjutnya tidak berpengaruh nyata pada parameter diameter batang bulan ke 1 , ke 2 dan ke 3, kemudian tidak berpengaruh nyata pada parameter jumlah daun bulan ke 1, ke 2, dan ke 3. Menurut Heddy (2002), setiap tanaman yang akan distimulir pertumbuhan tanaman dalam menerima rangsangan terhadap zat pengatur tumbuh sintetik berbeda-beda, pada konsentrasi yang terlalu rendah menyebabkan zat pengatur tumbuh kurang berperan sebagaimana mestinya, sedangkan pada konsentrasi yang terlalu tinggi akan bersifat racun bagi tanaman. Pada perlakuan pemberian ZPT Atonik tertinggi yaitu $\mathrm{z}_{3}$ dengan konsentrasi $1,5 \mathrm{ml} / 1$ liter air tidak menunjukkan pertumbuhan tunas lateral karena semakin tinggi kadar konsentrasi auksin yang diberikan pada tanaman maka akan menghambat pertumbuhan tunas lateral, sebaliknya jika sedikit kadar auksin yang diberikan akan mempercepat pertumbuhan tunas lateral. (Heddy, 2002).

\section{Pengaruh Perbandingan Media Tanam}

Tabel 2. Pengaruh Perbandingan Media Tanam (m) terhadap rata-rata tinggi tanaman $(\mathrm{cm})$

\begin{tabular}{cccc}
\hline \multirow{2}{*}{ Perlakuan Media Tanam } & \multicolumn{3}{c}{ Tinggi tanaman } \\
\cline { 2 - 4 } & Bulan ke 1 & Bulan ke 2 & Bulan ke 3 \\
\hline $\mathrm{m}_{0}$ & 6,46 & $20,50 \mathrm{a}$ & $24,00 \mathrm{a}$ \\
$\mathrm{m}_{1}$ & 6,46 & $20,50 \mathrm{a}$ & $23,42 \mathrm{a}$ \\
$\mathrm{m}_{2}$ & 6,71 & $11,83 \mathrm{~b}$ & $16,25 \mathrm{~b}$ \\
$\mathrm{~m}_{3}$ & 5,92 & $11,58 \mathrm{~b}$ & $16,58 \mathrm{~b}$ \\
\hline
\end{tabular}

Keterangan : Angka yang diikuti huruf yang sama menyatakan tidak berbeda nyata pada BNT 5\% (BNT $\mathrm{m}=4,07)$ tinggi tanaman umur bulan ke 2 dan pada BNT 5\% (BNT $m=3,00)$ tinggi tanaman umur bulan ke 3

Tabel 3. Pengaruh Perbandingan Media Tanam (m) terhadap rata-rata jumlah daun (helai)

\begin{tabular}{cccc}
\hline \multirow{2}{*}{ Perlakuan Media Tanam } & \multicolumn{3}{c}{ Jumlah daun } \\
\cline { 2 - 4 } & Bulan ke 1 & Bulan ke 2 & Bulan ke 3 \\
\hline $\mathrm{m}_{0}$ & $1,17 \mathrm{a}$ & 1,17 & 1,83 \\
$\mathrm{~m}_{1}$ & $1,25 \mathrm{a}$ & 1,17 & 2,08 \\
$\mathrm{~m}_{2}$ & $1,08 \mathrm{a}$ & 1,25 & 1,58 \\
$\mathrm{~m}_{3}$ & $0,50 \mathrm{~b}$ & 1,00 & 1,33 \\
\hline
\end{tabular}

Keterangan : Angka yang diikuti huruf yang sama menyatakan tidak berbeda nyata pada BNT 5\% (BNT m $=0,52)$

Hasil analisis sidik ragam menunjukkan bahwa perbandingan media tanam top soil + pasir + pupuk kandang $(1: 1: 1)$ (perlakuan $\left.\mathrm{m}_{1}\right)$ berpengaruh sangat nyata pada tinggi tanaman bulan ke 2 dan bulan ke 3, kemudian berpengaruh nyata pada jumlah daun pada bulan ke 1. Media top soil merupakan media yang ideal yang menumbuhkan semua tanaman, karena sifatnya yang mudah menyimpan unsur makro maupun mikro. Menurut Prihmantoro dan Idriyani (2003), media tanam sangat penting diperhatikan dalam mendukung pertumbuhan tanaman. Media yang baik yaitu dapat memasok sebagian unsur-unsur hara yang dibutuhkan oleh tanaman. Sebagian besar unsur hara yang dibutuhkan tanaman dipasok melalui media tanaman. Selanjutnya diserap oleh perakaran dan digunakan untuk proses fisiologis 
tanaman. Tiap jenis media tanam mempunyai bobot dan porositas yang berbeda. Dalam memilih media sebaiknya dicari kombinasi media tanam yang tepat sesuai dengan jenis tanaman. Sejalan dengan pendapat Rahmat (2005), bahwa media tanah + pasir merupakan media yang baik bagi pertumbuhan, hal ini disebabkan jenis media tanah campuran pasir mampu menggemburkan tanah sehingga perakaran bibit menjadi lebih baik untuk pertumbuhan tunas dan mampu mengatur drainase untuk penyerapan unsur hara seperti kalium yang diperoleh dari pupuk kandang serta hormon tumbuh yang diberikan akan lebih maksimal kegunaannya. Pupuk kandang tidak kalah pentingnya untuk menjamin ketersediaan unsur hara pada sembarang kondisi.
Hasil analisis sidik ragam menunjukkan bahwa perbandingan media tanam tidak berpengaruh nyata pada parameter tinggi tanaman bulan ke 1, selanjutnya tidak berpengaruh nyata pada parameter diameter batang bulan ke 1 , ke 2, dan ke 3. pH tanah sangat menentukan ketersediaan unsur hara. Menurut Hanafiah, (2005), Fosfor dan Nitrogen merupakan unsur yang harus disediakan pada tahap-tahap awal pertumbuhan untuk memastikan pertumbuhan vegetatif yang baik. Kondisi media yang masam akan menyebabkan kurangnya ketersediaan unsur hara $\mathrm{N}$ dan $\mathrm{P}$ sehingga pertumbuhan vegetatif tanaman akan terganggu.

\section{Pengaruh Interaksi Perbandingan ZPT Atonik dan Media Tanam}

Tabel 4. Pengaruh Interaksi Perbandingan ZPT Atonik dan Media Tanam terhadap rata-rata jumlah daun (helai)

\begin{tabular}{|c|c|c|c|}
\hline \multirow{2}{*}{$\begin{array}{l}\text { Perlakuan ZPT Atonik } \\
\text { dan Media Tanam }\end{array}$} & \multicolumn{3}{|c|}{ Jumlah daun } \\
\hline & Bulan ke 1 & Bulan ke 2 & Bulan ke 3 \\
\hline $\mathrm{z}_{0} \mathrm{~m}_{0}$ & $1,67 \mathrm{ab}$ & 1,67 & 2,00 \\
\hline $\mathrm{z}_{1} \mathrm{~m}_{0}$ & $1,00 \mathrm{abc}$ & 1,00 & 1,67 \\
\hline $\mathrm{z}_{2} \mathrm{~m}_{0}$ & $1,00 \mathrm{abc}$ & 1,00 & 2,00 \\
\hline $\mathrm{z}_{3} \mathrm{~m}_{0}$ & $1,00 \mathrm{abc}$ & 1,00 & 1,67 \\
\hline $\mathrm{z}_{0} \mathrm{~m}_{1}$ & $1,00 \mathrm{abc}$ & 1,00 & 2,00 \\
\hline $\mathrm{z}_{1} \mathrm{~m}_{1}$ & $1,00 \mathrm{abc}$ & 1,00 & 1,67 \\
\hline $\mathrm{z}_{2} \mathrm{~m}_{1}$ & $1,00 \mathrm{abc}$ & 1,00 & 1,67 \\
\hline $\mathrm{z}_{3} \mathrm{~m}_{1}$ & $2,00 \mathrm{a}$ & 1,67 & 3,00 \\
\hline $\mathrm{z}_{0} \mathrm{~m}_{2}$ & $0,33 \mathrm{c}$ & 1,00 & 1,00 \\
\hline $\mathrm{z}_{1} \mathrm{~m}_{2}$ & $1,67 \mathrm{ab}$ & 1,67 & 2,00 \\
\hline $\mathrm{z}_{2} \mathrm{~m}_{2}$ & $1,67 \mathrm{ab}$ & 1,33 & 2,33 \\
\hline $\mathrm{z}_{3} \mathrm{~m}_{2}$ & $0,67 \mathrm{bc}$ & 1,00 & 1,00 \\
\hline $\mathrm{z}_{0} \mathrm{~m}_{3}$ & $1,00 \mathrm{abc}$ & 1,00 & 1,33 \\
\hline $\mathrm{z}_{1} \mathrm{~m}_{3}$ & $0,33 \mathrm{c}$ & 1,00 & 1,33 \\
\hline $\mathrm{z}_{2} \mathrm{~m}_{3}$ & $0,67 \mathrm{bc}$ & 1,00 & 1,67 \\
\hline $\mathrm{z}_{3} \mathrm{~m}_{3}$ & $0,00 \mathrm{c}$ & 1,00 & 1,00 \\
\hline
\end{tabular}

Keterangan : Angka yang diikuti huruf yang sama menyatakan tidak berbeda nyata pada BNT 5\% (BNT $m=1,05)$

Hasil analisis sidik ragam menunjukkan bahwa pengaruh interaksi perbandingan ZPT Atonik dan media tanam berpengaruh nyata pada jumlah daun bulan ke 1, ZPT Atonik dengan konsentrasi $1,5 \mathrm{ml} / 1$ liter air dengan media top soil + pasir + pupuk kandang $=1: 1: 1$ $\left(\mathrm{Z}_{3} \mathrm{P}_{1}\right)$ dan $\mathrm{ZPT}$ Atonik dengan konsentrasi 0,5 $\mathrm{ml} / 1$ liter air dengan perbandingan media top soil + arang sekam + pupuk kandang $=1: 1: 1$ $\left(\mathrm{Z}_{1} \mathrm{P}_{2}\right)$. Menurut Wuryaningsih (2000), top soil +Arang sekam + pupuk kandang mengandung $\mathrm{N}$ $32 \%$, PO $15 \%$, KO $31 \%$, Ca 0,95\%, dan Fe
180 ppm, Mn 80 ppm, Zn 14,1 ppm dan pH 6,8. Karakteristik lain dari top soil + arang sekam + pupuk kandang adalah ringan, Sirkulasi udara tinggi, kapasitas menahan air tinggi, mengikat air, tidak mudah menggumpal.

Media top soil + arang sekam + pupuk kandang, unsur hara yang dimiliki jumlah yang paling berlimpah adalah unsur N. Seperti yang telah kita ketahui bahwa kandungan $\mathrm{N}$ (Nitrogen) sangat dibutuhkan tanaman saat proses pembentukan daun dan batang Harjadi, (2009). 


\section{KESIMPULAN}

1. Pengaruh ZPT Atonik (Z) yang terbaik pada tinggi tanaman bulan ke 1 dicapai oleh perlakuan $\mathrm{z}_{2}$ (dengan konsentrasi $1 \mathrm{ml} / 1$ liter air).

2. Perbandingan media tanam (M) yang terbaik terhadap tinggi tanaman bulan ke 2 dan bulan ke 3 dicapai oleh $m_{2}$ (top soil + arang sekam + pupuk kandang $=1: 1: 1)$. Sedangkan perbandingan media tanam $(\mathrm{P})$ yang terbaik terhadap parameter jumlah daun dicapai oleh perlakuan $\mathrm{m}_{2}$ (top soil + arang sekam + pupuk kandang $=1: 1: 1)$ dan perlakuan $m_{3}$ (Top soil + arang sekam + pasir + pupuk kandang $=1: 1: 1: 1)$. Selanjutnya perlakuan yang terbaik pada parameter jumlah daun bulan ke 1 dicapai oleh perlakuan $\mathrm{m}_{1}$ (top soil + pasir + pupuk kandang $=1: 1: 1$ )

3. Interaksi perbandingan ZPT Atonik dan media tanam (ZxM) yang terbaik pada jumlah daun bulan 1 dicapai oleh $\mathrm{z}_{3} \mathrm{~m}_{1}$ (ZPT Atonik dengan konsentrasi 1,5 ml/ 1 liter air dan perbandingan media top soil + pasir + pupuk kandang $=1: 1: 1$ ).

\section{DAFTAR PUSTAKA}

Chan, E. 2000.Tropical Plants of Southeast Asia.Periplus Edition. (HK) Ltd. Printed in Singapore.

Elsje $\mathrm{T}$ Tenda, Donata S. Pandin, Ismail Maskromo. 2011. Balai Penelitian Tanaman Kelapa dan Palma Lain. Prosiding Seminar Nasional Inovasi Perkebunan.

Harjadi, Sri. Setyati. 2009. Zat Pengatur Tumbuh. Penebar Swadaya. Jakarta.

Hanafiah, K.A., 2007. Rancangan Percobaan Aplikatif. Raja Grafindo Persada. Jakarta

Hanafiah, K, A., 2005. Dasar-dasar Ilmu Tanah. Raja Grafindo Persada. Jakarta.

Lempang , M. dan Soenarno, 1999. Teknik Penyadapan Aren untuk Meningkatkan Produksi Nira. Prosiding Ekspose HasilHasil Penelitian. Balai Penelitian Kehutanan, Ujung Pandang. Hal 25-35.

Lempang, M., 2000. Rendemen Produksi Gula Aren (Arenga pinnata Merr.). Buletin Penelitian Kehutanan Vol.6 No.1 Tahun 2000. Balai Penelitian Kehutanan, Ujung Pandang. Hal 17-28.
Lempang, M., 2006. Rendemen dan Kandungan Nutrisi Nata Pinnata Yang Diolah dari Nira Aren. Jurnal Penelitian Hasil Hutan Vol.24 No.2 Tahun 2006. Pusat Penelitian dan Pengembangan Hasil Hutan, Bogor. Hal 133-144.

Novizan, 2002. Petunjuk Pemupukan Yang Efektif. AgroMedia Pustaka. Jakarta.

Prihmantoro, H. Dan Y. H. Indriyani. 2003. Hidroponik Sayuran Semusim Untuk Hobi dan Bisnis. Penebar Swadaya. Jakarta.

Ramadani P., I. Khaeruddin, A. Tjoa dan I.F. Burhanuddin. 2008. Pengenalan JenisJenis Pohon Yang Umum di Sulawesi. UNTAD Press, Palu.

Sanjaya, L, R. Meilasari, dan K. Budiarto. 2004. Pengaruh Nitrogen dan Gibberellin Pada Dua Sistem Pembudidayaan Tanaman Induk Krisan. Prosiding Seminar Nasional FloriKultura. Hlm. 228-236. Makalah.

Surata, I.K. 2008. Penggunaan Zat Pengatur Tumbuh Rootone-F pada Stump Cendana (Santalum album Linn). Jurnal Penelitian Hutan Tanaman. Vol. 5.

Soeseno. 2000. Bertanam Aren. Penebar Swadaya. Jakarta.

Wuryaningsih, S. 2000. Perngaruh Kultivar IBA, dan Bahan Setek Pada Perbanyakan Melati. Jurnal Agrotropika. Vol. V (2).

Yunita, R. 2011. Pengaruh Pemberian Urin Sapi, Air Kelapa, dan Rootone F Terhadap Pertumbuhan Setek Tanaman Markisa (Passiflora edulis Var. Flavicarpa) Solok. Hal 1-10. 